\title{
$\angle$ Research Square \\ Salicylic acid application alleviates Cadmium accumulation in brown rice by modulating its shoot to grain translocation in rice
}

Wang Feijuan ( $\nabla$ wfj0311@cjlu.edu.cn )

China Jiliang University https://orcid.org/0000-0002-8087-1089

\section{Tan Haifeng}

China Jiliang University

\section{Zhang Yiting}

China Jiliang University

\section{Huang Lihong}

China Jiliang University

\section{Ding Yanfei}

China Jiliang University

\section{Chen ZhiXiang}

China Jiliang University

\section{Zhu Cheng}

China Jiliang University

\section{Original article}

Keywords: Cadmium, Salicylic acid, Rice, Cd accumulation, SA-signaling pathway

Posted Date: December 31st, 2019

DOI: https://doi.org/10.21203/rs.2.19653/v1

License: @ (i) This work is licensed under a Creative Commons Attribution 4.0 International License. Read Full License 


\section{Abstract}

Cadmium (Cd) contamination has been recognized as a major threat to the agricultural system and crop production which posing serious threat to human health. Salicylic acid (SA) serves as an important signaling molecule and plays an important role in against $\mathrm{Cd}$ toxicity. In the previous field experiments, we found SA spraying could reduce the Cd accumulation of rice grain grown in Cd-contaminated soil. This study investigated the effects and mechanisms of SA spraying on leaves of rice seedlings under Cd stress. Results showed that SA treatment could alleviate the Cd toxicity of rice not by changing the physical and chemical properties of the soil, but by increasing the activities of antioxidant enzymes to reduce the $\mathrm{H} 2 \mathrm{O} 2$ accumulation in rice. And the key factor of SA treatment reducing Cd accumulation in rice grain was the decreasing of $\mathrm{Cd}$ contents in rice leaves at the flowering stage. This indicated that SA could modulate the $\mathrm{Cd}$ accumulation of shoots to reduce the $\mathrm{Cd}$ translocation to rice grain. Furthermore, SA could increase the $\mathrm{H} 2 \mathrm{O} 2$ contents in a short-term to activate the SA-signaling pathway, and modulate the expression levels of Cd transporters ( OsLCT1 and OsLCD ) in rice leaves toraise Cd tolerance and reduce $\mathrm{Cd}$ accumulation in rice grain. Thus, SA spraying can be used as an effective measure to cope with Cd contamination in paddy soils.

\section{Introduction}

Growing population and fast industrialization coincide together, results in the generation and dissemination of huge amount of toxic metals in the environment (Hasanuzzaman et al., 2012). Cd is one of the most phytotoxic heavy metals which have no biological role in plants, and its contamination in agricultural soil has become a great problem for crop production in recent decades. As a common soil pollutant, $\mathrm{Cd}$ can accumulate in plant tissues to cause toxicity and enter human through the food chain and drinking water to cause diseases in kidney, bone and respiratory system and cancers (Zhou et al., 2017). Rice is an important staple food for nearly half of the world's population (Valipour et al. 2015) and is also a major source of Cd uptake for people. Consumption of Cd-contaminated rice caused the outbreak of "Itai-Itai disease" in the mid-20 ${ }^{\text {th }}$ century in Japan. Recently, Cd-contaminated rice has also occurred in China, which poses important public health risks (Liu et al., 2016b). Therefore, it is essential to produce low-Cd rice to reduce the potential risks that $\mathrm{Cd}$ poses to human health.

Defense mechanisms induced by $\mathrm{Cd}$ stress in plants have been revealed by focusing on mechanisms of its toxicity, tolerance and accumulation. The rapid production and accumulation of reactive oxygen species (ROS), especially $\mathrm{H}_{2} \mathrm{O}_{2}$ was often accompanied with Cd stress (Muhammad et al., 2019; Zoltán et al., 2018; Wei et al., 2018). Previous studies indicated that SA could alleviate the Cd toxicity (Ahmadet al. 2019; Wei et al. 2018; Guo et al., 2018; Qiao et al., 2015) and reduce Cd uptake and its distribution (Yotsova et al, 2018; Liu et al. 2016a; Shakirova et al. 2016). SA is a ubiquitous plant phenolic compound that has been used in many plant species to alleviate Cd toxicity by participating in the signal transduction pathways (Yotsova et al, 2018; Zoltán et al., 2018; Jini and Joseph, 2017; Liu et al., 2016a; Wani et al., 2017; Agami and Mohamed, 2013; Vlot et al., 2009). A number of reports indicated that SA not only plays a pro-oxidant role, but also controls cellular redox homeostasis through the regulation of antioxidant enzyme activities under stress conditions (Emad et al, 2019; Zoltán et al., 2018; Herrera-Vásquez et al., 2015; Xia et al., 2015). SA could increase the activity of superoxide dismutase (SOD), the main scavenger of superoxide radicals, which catalyses the conversion of superoxide to $\mathrm{H}_{2} \mathrm{O}_{2}$ in different cell compartments, and SA also could inactivate catalases (CAT) and ascorbate peroxidases (APX), two types of $\mathrm{H}_{2} \mathrm{O}_{2}$ scavengers, thus leading to $\mathrm{H}_{2} \mathrm{O}_{2}$ accumulation (Amit et al., 2015; Rao et al., 1997).

Many studies have reported that $\mathrm{H}_{2} \mathrm{O}_{2}$ can act together with $\mathrm{SA}$ in a self-amplifying feedback loop where SA induced $\mathrm{H}_{2} \mathrm{O}_{2}$ accumulation, which then enhanced the accumulation of SA (Zoltán et al., 2018; Xia et al., 2015; Wi et al., 2010). And endogenous SA could enhance and bind to CAT to increase the level of $\mathrm{H}_{2} \mathrm{O}_{2}$, the $\mathrm{H}_{2} \mathrm{O}_{2}$ serves as secondary 
messenger to induce the expression of tolerance-related genes (Amit et al., 2015; Guo et al., 2009). Furthermore, $\mathrm{H}_{2} \mathrm{O}_{2}$ also could induce the accumulation of SA (Guo P et al., 2017; Leon et al., 1995). Therefore, the production of $\mathrm{H}_{2} \mathrm{O}_{2}$ during Cd stress served as part of the signaling cascade, and increased levels of ROS might interact with SA (Orsolya et al, 2016). Pape et al. (2010) reported that SA promoted the redox modification of specific Cys residues and the monomerisation of the oligomeric form of the NPR1 (NON-EXPR- ESSOR OF PR GENES 1) transcription coactivator, a central compound of SA signaling pathway, which was transported to the nucleus and interacted with certain TGA transcription factors (TGA2 and TGA3), the regulators of SA-dependent late genes (e.g. PATHOGENESIS RELATED1, PR1 gene). Class II TGA transcription factors (TGA2/5/6) were also essential regulators in SA-induced gene expression, but they mediated the NPR1-independent induction of early defense genes including antioxidant enzymes (Zoltán et al., 2018; Blanco et al., 2009). Hence, SA was not only known to induce a wide range of cellular defense reactions, but also could modulate the gene expression of plants responded to different stresses (Biswaset al. 2019).

In the previous field experiments, we found that SA spraying could reduce the $\mathrm{Cd}$ accumulation of rice grain grown in $\mathrm{Cd}$-contaminated soil. However, the study on the reduction of $\mathrm{Cd}$ accumulation in rice grain by SA application is still blank. Thus, we conducted a pot experiment in the laboratory to screen the best concentration of SA treatment, and declare its molecular and physiological mechanism in regulating $\mathrm{Cd}$ accumulation of rice.

\section{Materials And Methods}

\subsection{Growth Conditions and Experimental Design}

Seeds of the pre-screened as a high grain-Cd-accumulating rice (Xiushui 110) was used in the pot experiment. After germination, rice seedlings were grown in a grid until to 4-leaf stage (Wang et al., 2009), then the plants were transplanted into the plastic pots filled with $10.0 \mathrm{~kg}$ soil, four seedlings were grown in each pot. After treated with $\mathrm{Cd}$ for 1 week, the pre-screened $0.1 \mathrm{mM}$ SA solutions and 0.1mM AOPP (L-2-aminooxygen-3-phenyl acrylic acid, synthetic inhibitors of SA) were sprayed on the seedlings' leaves until the whole leaves were covered by the solutions at the tillering stage, heading stage and flowering stage, respectively. The experimental groups were set up 6 experimental groups: CK (control, without Cd or SA treatment), Cd (single Cd treatment), SA (single SA treatment), SA+Cd (treated with SA under Cd stress), AOPP (treated with AOPP), AOPP+Cd (treated with AOPP under Cd stress).

\subsection{Estimation of the agronomic traits of rice}

Samples were collected from each pot at the growth stages after sprayed with SA (or AOPP) for 5 days and at the maturity stage, respectively. The rice plants height and root length were measured by a ruler. The dry matter accumulation was determined as follows: The plants were divided into roots and shoots, then dried in the oven for $2 \mathrm{~h}$ at $105^{\circ} \mathrm{C}$ and baked at $70^{\circ} \mathrm{C}$ to constant weight. The 1000 -grain weight was also analyzed.

\subsection{Estimation of the $\mathrm{pH}$, available $\mathrm{Cd}$ and total $\mathrm{Cd}$ in soil}

The soils at different stages of rice plants were used in the determination, and the sampled soil was naturally air-dried and removed through a $2.5 \mathrm{~mm}$ nylon screen to remove grit and plant debris, then passed through a 100-mesh screen and stored. The $\mathrm{pH}$, available $\mathrm{Cd}$ and total $\mathrm{Cd}$ were determined according to Wang et al. (2018).

\subsection{Estimation of Cd contents in different parts of rice}

Different parts of rice samples were taken at heading and flowering stages after sprayed with SA for 5 days and at the maturity stage, respectively. Roots of rice samples were immersed in $20 \mathrm{mM}$ disodium ethylenediamine tetra-acetic acid $\left(\mathrm{Na}_{2}-\mathrm{EDTA}\right)$ for $20 \mathrm{~min}$, and then rinsed three times with deionized water. All the rice samples were dried at $105^{\circ} \mathrm{C}$ for $2 \mathrm{~h}$ 
firstly, then baked at $70^{\circ} \mathrm{C}$ to achieve a constant weight, and finally ground to powders. Each $0.3 \mathrm{~g}$ dried rice powders were treated with $6 \mathrm{~mL} \mathrm{HNO}_{3}$ (brown rice) or $6 \mathrm{~mL} \mathrm{HNO}_{3}$ plus $0.5 \mathrm{ml} \mathrm{H}_{2} \mathrm{O}_{2}$ (other rice samples) to digest in a microwave digester (CEM-MARS, Boston, USA). After digestion, all the mixtures were driven acid to $1 \mathrm{~mL}$ at elevated temperature. The solutions were then diluted into $25 \mathrm{~mL}$ volumetric flasks with ultra-pure water, and the clarified samples thus obtained were kept in a refrigerator at $4{ }^{\circ} \mathrm{C}$ for further analysis. The $\mathrm{Cd}$ contents were determined by an atomic absorption spectrometer (AA7000, SHIMADZU, and Kyoto, Japan).

\subsection{Estimation of endogenous SA content and PAL activity}

Fresh leaves $(0.1 \mathrm{~g})$ were ground with liquid nitrogen into power, and added $0.5 \mathrm{~mL}$ sterile water, then carried out ultrasonic $30 \mathrm{~min}$. The homogenate was placed in centrifuge at $10,000 \mathrm{rpm}$ for $10 \mathrm{~min}$, and the supernatant obtained was the sample extract. Finally, the endogenous SA content was measured by the Plant Salicylic acid (SA) ELISA Kit (JM-E100150, U.S.A TSZ biological Trade Co., Ltd). The determination of PAL activity was followed with the instructions of the specific Kit (A173, Nanjing Institute of Bioengineering).

\subsection{Estimation of $\mathrm{H}_{2} \mathrm{O}_{2}$ and antioxidant enzymes}

Fresh leaves $(0.1 \mathrm{~g})$ were ground with liquid nitrogen into power, then ground with $3 \mathrm{ml}$ precooled extraction buffer solution (50mM PBS, $\mathrm{pH} 7.0$ ), and finally the homogenate was used for the determination of $\mathrm{H}_{2} \mathrm{O}_{2}$ and the activity of $P O D, C A T$ and SOD. All the indexes were measured using Amplex ${ }^{\circledR}$ Red Hydrogen Peroxide/Peroxidase Assay Kit (A22188, invitrogen), POD test kit (A084-3, Nanjing jiancheng Bioengineering Research Institute), CAT test kit (A007-1, Nanjing jiancheng Bioengineering Research Institute) and SOD test kit (A001-3, Nanjing jiancheng Bioengineering Research Institute), respectively.

\subsection{Gene expression analysis using qRT-PCR}

Total RNA isolated from the top 2nd leaves of rice plants after SA sprayed for 5days at the flowering stage, and the different $c D N A$ were synthesized with the primerscript ${ }^{\mathrm{M}} \mathrm{RT}$ reagent kit (Takara, Japan). Primer sequences used were listed in Table 1, $\beta$-actin was chosen as the internal control. The qRT-PCR was performed using a Rotor-Gene Q machine (parameters: $10 \mathrm{~min}$ at $95^{\circ} \mathrm{C}$, followed by 45 cycles of $10 \mathrm{~S}$ at $95^{\circ} \mathrm{C}, 15 \mathrm{~S}$ at $58^{\circ} \mathrm{C}$, and $15 \mathrm{~S}$ at $72^{\circ} \mathrm{C}$ ). All the reactions were performed in triplicate (technical replicates) for each biological replicate (three for each treatment). Quantification of gene expression was calculated using $\triangle \triangle \mathrm{CT}$ method (Wang et al., 2012).

\subsection{Statistical analysis}

The experimental data was analyzed using the Prism software (Graphpad Prism 6.0, GraphPas Software Inc., SanDiego, California, USA) and presented as the mean \pm standard deviation (SD) which calculated with at least three replicates. Student's $t$-test was adopted for the analysis of significant differences among the treatments. $P$-value less than 0.05 were considered as significant.

\section{Results}

\subsection{SA application enhances the tolerance to $\mathrm{Cd}$ in rice}

Preliminary experiments showed that SA played an important role at the reproductive growth period (data not shown). Therefore, our experiments were conducted mainly at the reproductive growth stages (heading stage, flowering stage and mature stage). Cd stress obviously reduced seedlings growth, which mainly reflected in the following aspects: root length, plant height, shoot Dw plant-1, and1000-grain weight. SA application could relieve the Cd toxicity obviously, 
increased the plant height and shoot Dw plant-1 evidently of the Cd-exposed rice plants, but there was no significant difference between $\mathrm{Cd}$ and AOPP+Cd groups (Table 2 and 3), the same trends were observed at all the three stages of rice plants. In addition, application of SA or AOPP to non-stressed seedlings did not result in any difference in agronomic traits.

\subsection{SA application alleviates the $\mathrm{Cd}$ accumulation in rice grain by the reduction of $\mathrm{Cd}$ content in leaves at flowering stage}

2.2.1 SA application changed the physical and chemical properties the soil

From the analysis of the effects of SA and AOPP application on the total Cd content, available Cd content and $\mathrm{pH}$ value of the soil, we found the total $\mathrm{Cd}$ and the available $\mathrm{Cd}$ contents of the soil were decreased continuously during the growth of rice. And the exogenous SA or AOPP treatment did not affect the total Cd and the available Cd contents at the four different stages obviously except there was a significant difference between SA+Cd group and AOPP+Cd group at the mature stage. Furthermore, the $\mathrm{pH}$ value of the Soil also was not changed after the treatment with exogenous SA or AOPP (data not shown).

\subsubsection{SA application induces low $\mathrm{Cd}$ accumulation in rice grain}

Cd accumulation of rice grain $(0.29 \mathrm{mg} / \mathrm{kg})$ in Cd-exposed rice plants was significantly greater than the regulatory $\mathrm{Cd}$ limit $(0.2 \mathrm{mg} / \mathrm{kg})$, but SA application could reduced the accumulation of $\mathrm{Cd}$ to $0.12 \mathrm{mg} / \mathrm{kg}$. Meanwhile, the AOPP+Cd group increased Cd accumulation $(0.34 \mathrm{mg} / \mathrm{kg})$ significantly which was higher than that of the Cd group (Figure 1).

\subsubsection{SA application decreases the Cd contents in other parts of rice}

The rice plants accumulated significant amount of $\mathrm{Cd}$ in different parts during $\mathrm{Cd}$ stress, and the roots accumulated the most Cd by nearly $80 \%$. Compared with the Cd-exposed rice plants, application of SA could reduce the Cd accumulation of leaves and flag leaves remarkable, especially the leaves at flowering stage (around $45 \%$ reduction), resulted in around $53 \%$ reduction of $\mathrm{Cd}$ accumulation in panicle. However, SA application had no significant impact on $\mathrm{Cd}$ accumulation in roots, stems and nodes. Furthermore, AOPP application significantly enhanced the total Cd accumulation in panicle, and the main reason was that the $\mathrm{Cd}$ contents in leaves at flowering stage were increased (Figure 2). Therefore, we indicated the main reason of SA treatment could effectively reduce Cd content in brown rice and panicles was SA could significantly reduce $\mathrm{Cd}$ contents in rice leaves at flowering stage.

Different treatments could affect the mobility of $\mathrm{Cd}$ in rice. From the analysis of effect of the three groups $(\mathrm{Cd}, \mathrm{SA}+\mathrm{Cd}$ and $\mathrm{AOPP}+\mathrm{Cd}$ ) on the $\mathrm{Cd}$ mobility in rice, we only found the $\mathrm{Cd}$ mobility at flowering stage (stem-to-leaf and leaf-topanicle) and mature stage (leaf-to-panicle) were shown obvious significance (Table 4). SA application could markedly reduce the Cd mobility, as well as AOPP application could markedly increase the Cd mobility in stem-to-leaf at flowering stage. Furthermore, the different $\mathrm{Cd}$ mobility resulted in the different $\mathrm{Cd}$ accumulation in rice panicles, SA application both reduced the $\mathrm{Cd}$ mobility in leaf-to-panicle approximately both $41 \%$ at flowering stage and mature stage, and AOPP application increased the Cd mobility in leaf-to-panicle about $47 \%$ at flowering stage and $29 \%$ at mature stage separately. Therefore, leaves at flowering stage were the critical parts for SA regulate Cd accumulation in rice grain.

\subsection{SA application boosts endogenous SA accumulation and activates the SA-signaling pathway}

\subsubsection{Application of SA boosts endogenous SA accumulatin in rice}

As leaves at the flowering stage were the key parts for SA regulating Cd accumulation in rice grain, we determined the content of SA in rice leaves at flowering stage. SA and AOPP applications both had a significant impact on SA contents 
in leaves. Without Cd stress, SA treatment could obviously increase the SA contents in rice and AOPP treatments could obviously reduce the SA contents in rice. During Cd stress, SA application showed a time dependent increase of the SA contents in leaves, reached the maximum on the 3rd day by $94 \%$ than control, and then began to decrease on the 5 th day; AOPP treatment reduced by about $80 \%$ than control (Figure 3 ).

Moreover, the differently biosynthesis of SAin different plant species were contribute to the activities of PAL and ICS enzymes (Xu et al. 2017).We found Cd stress could decrease the expression of PAL enzyme, and SA application could induce higher PAL expression (Figure 4). The expression of OSPAL in SA group were higher than that of CK group, it could arrived at more than 2 times at 6 hours after SA application at the flowering stage, as well as the expression level of OsPAL in SA+Cd group were more than 2.5 times than that of $\mathrm{Cd}$ group at 6 hours. In contrast to the changes of OsPAL expression level, there were no significance of the expression levels of OsICS between CK and Cd group, but the expression levels of Os/CS in SA (or SA+Cd) group could increase by more than 4 times than that of WT (or Cd) group, respectively.

\subsubsection{SA application regulates the expression of key genes in SA-signaling pathway}

It was generally known that SA signaling in rice was mediated by NPR1 and the WRKY sub-pathway (Xu et al. 2017; Nakayama et al. 2013). We found the expression of OsNPR1, OsWRKY45, OsWRKY7, and OsWRKY70 were all modulated by Cd stress, and the SA application could increase the expression of OsNPR1 and OsWRKY45 obviously (Figure 5). The trends of the OSWRKY45expressionwhich represented the SA level in rice in different experimental groups were consistent with the SA levels (Amit et al., 2015; Shimono et al., 2007; Ryu et al., 2006), these results suggest that SA enhancedOsWRKY45expression resulted in an raise of endogenous SA content. OsWRKY7 and OsWRKY70 were also found related with the SA level in rice seedlings (Xu et al., 2017). Our results indicated that the expression levels of OSWRKY7 and OSWRKY7O were negatively correlated with the SA contents in rice.

\subsection{SA application sustains a high level of $\mathrm{H}_{2} \mathrm{O}_{2}$ and boostsantioxidant enzymes' activities under Cd stress}

In order to examine whether SA induces $\mathrm{H}_{2} \mathrm{O}_{2}$ production in rice leaves during $\mathrm{Cd}$ stress, the contents of $\mathrm{H}_{2} \mathrm{O}_{2}$ and enzyme activities of CAT, POD, and APX in the rice leaves at the flowering stage were determined. Results showed that Cd stress could result in a high $\mathrm{H}_{2} \mathrm{O}_{2}$ accumulation. The $\mathrm{H}_{2} \mathrm{O}_{2}$ content in SA group was reduced in a short period of time after $\mathrm{SA}$ application, the $\mathrm{H}_{2} \mathrm{O}_{2}$ content was lowest on the 1 st day, then increased continuously, and returned to the same level as the control on the 5th day, similar trend was observed in $\mathrm{SA}+\mathrm{Cd}$ group. Furthermore, the $\mathrm{H}_{2} \mathrm{O}_{2}$ content in $\mathrm{SA}+\mathrm{Cd}$ group was higher than that of the Cd group temporary, but after SA application it decreased with time to the lowest level on the 3rd day, and then increased to the level similar with the Cd group on the 5th day (Figure 6).

Furthermore, compared with the Cd group, the activities of antioxidant enzymes (such as SOD, POD and CAT) in SA group and $\mathrm{Cd}+\mathrm{SA}$ group showed a similar enhancement moderated by SA treatment (Figure 6). It was obvious that SA application on rice leaves during $\mathrm{Cd}$ stress could increase the $\mathrm{H}_{2} \mathrm{O}_{2}$ content in a short-term and improve the Cd tolerance of rice.

\subsection{SA application modulates the expression level of genes related to Cd accumulation}

Two genes related to $\mathrm{Cd}$ accumulation of rice grain in rice were detected in this experiment. OsLCT1which was reported could mediate $\mathrm{Cd}$ transport in the phloem of rice (Uraguchi et al., 2014). As shown in figure 7, Cd group could decrease the expression level of OsLCT1 by around $80 \%$ than that of the control, and SA group enhanced the OsLCT1 expression significantly in comparison to control. Compared with the Cd group, SA+Cd group could obviously enhance the OSLCT1 expression though the level was lower than the control. 
OsLCD was found related to the Cd tolerance and accumulation (Shimo et al., 2011), there was no significant change of the OsLCD expression in Cd group in comparison to the control, except for SA application (SA group or SA+Cd group) (Figure 7). SA group and SA+Cd group could increase the $O s L C D$ expression in a short time, and then quickly dropped to its original level.

\section{Discussion}

Cd stress has been recognized as a major threat to the agricultural system and crop production.SA serves as an important signaling molecule in plant system which has been shown to play role in against Cd toxicity (Ahmadet al. 2019; Liu et al. 2016a; Abdul et al. 2016; Amit et al., 2015; Qiao et al. 2015; Noriega et al., 2012; Metwally et al., 2003). However, few studies regarding SA modulates $\mathrm{Cd}$ accumulation in rice have been reported. Here we found SA spraying could not only effectively improve the $\mathrm{Cd}$ tolerance in rice, but also reduce the $\mathrm{Cd}$ accumulation in rice grain.

SA spraying could effectively improve the Cd tolerance. The main manifestations were as follows: SA treatment increased the $\mathrm{H}_{2} \mathrm{O}_{2}$ contents temporary as well as boost antioxidant enzymes activities under Cd stress; Increased the expression level of PAL and ICS enzymes to boost the activities of PAL and ICS enzymes, then boost the endogenous SA accumulation as a signaling molecule, which will activate the SA-signaling pathway to induce the expressions of specific proteins or defense-related enzymes (Liu et al. 2016a;Zawoznik et al. 2007); SA was a scavenger of hydroxyl radical $(\mathrm{OH})$, the increased endogenous SA induced by SA application could reduce the Cd toxicity in rice (Abdul et al. 2016). That phenomenon may confirm that relationship between $\mathrm{H}_{2} \mathrm{O}_{2}$ and SA (Liu et al. 2016a; Abdul et al. 2016; Qiao et al., 2015; Amit et al. 2015). It was known that SA could act together with $\mathrm{H}_{2} \mathrm{O}_{2}$ in a self-amplifying feedback loop where SA induce $\mathrm{H}_{2} \mathrm{O}_{2}$ accumulation, which then enhanced the accumulation of SA (Zoltán et al., 2018; Xia et al., 2015; Wi et al., 2010). Our results indicated that SA treatment had no change on the physical and chemical properties of the soil, but significantly increased the activities of SOD, POD and CAT in rice under Cd stress, which could relieve the damage of a short-term increased $\mathrm{H}_{2} \mathrm{O}_{2}$. These results were consistent with the previous reports (Ahmadet al, 2019; Liu et al, 2016a; Guo et al. 2007, 2009). However, some reports showed that SA could indirectly decrease $\mathrm{H}_{2} \mathrm{O}_{2}$ accumulation by elevating antioxidant enzymes activities (Bai et al. 2014; Wang et al. 2013a), SA application could decreased the activities of antioxidant enzymes (SOD, CAT and POD) (Jini and Joseph, 2017), and SA could interact with CAT to inhibit its activity, then causing excessive $\mathrm{H}_{2} \mathrm{O}_{2}$ accumulation (Qiao et al., 2015; Sajitha and Murugan 2010). Therefore, the protective impact of SA on Cd tolerance in rice was time-dependent and dose-dependent.

In addition, SA could modulate the $\mathrm{Cd}$ accumulation of shoots to reduce the $\mathrm{Cd}$ translocation to rice grains. Our results showed that SA treatment had no significant impact on Cd accumulation in roots, stems and nodes, except the Cd contents in leaves at flowering stage. Furthermore, SA could significantly reduce the Cd mobility of stem-to-leaf and leaf-to-panicle in rice at flowering stage which resulted in low $\mathrm{Cd}$ accumulation in rice grain. It was not exactly consistent with the previous studies reported that SA regulated mainly the $\mathrm{Cd}$ uptake in rice, and then mediated the $\mathrm{Cd}$ translocation of root-to-shoot (Bai et al. 2014; Wang et al. 2013b; Noriega et al 2012). Such as Bai et al. (2014) report that SA treatment reduced the $\mathrm{Cd}$ accumulation both in roots and shoots in perennial ryegrass, Wang et al. (2013b) report that SA treatment increased the $\mathrm{Cd}$ accumulation in roots but significantly reduced it in the shoots in rice seedlings, Saidi et al. (2013) report SA application could decrease the Cd uptake and transport in Bean. Thus, the difference between our experiment and the previous studies is the spraying of SA at a certain concentration on the leaves in our experiment. Therefore, this might be due to SA-mediated the $\mathrm{Cd}$ transporters in rice leaves which result in the low-Cd in rice grain.

In present studies, OsLCT1 and OsLCD were usually recognized as two key genes which could mediate Cd transport in the phloem of rice (Uraguchi et al., 2014; Shimo et al., 2011). Our results showed that Cd 
contents in leaves at flowering stage decreased were the critical factor in the low Cd accumulation in rice grain under $\mathrm{Cd}$ stress. Through analyzing the expression of the two $\mathrm{Cd}$ transporters, results indicated SA could induce higher expression level of OSLCT1and OSLCD under Cd stress while the expression level of OsLCD was enhanced briefly. Therefore, it might be possible that most of $\mathrm{Cd}$ accumulated in rice plants with SA treatment was sequestered in root vacuoles, as a result less $\mathrm{Cd}$ could be transported to the shoot, and then low $\mathrm{Cd}$ accumulated in leaves. Second, although the outward transport capacity of $\mathrm{Cd}$ in leaves increased, more $\mathrm{Cd}$ in leaves were sequestered in leaves vacuoles or SA act as an Cd-chelation (Abdul et al. 2016), led to the Cd transport was less in leaves of SA+Cd group, finally lower $\mathrm{Cd}$ accumulation in rice grain.

It was reported that SA was a defense hormone, the SA signaling in rice could mediate many kinds of resistance in plants, and SA signaling in rice was mediated by NPR1 and the WRKY sub-pathway (Zhao et al. 2019; Yotsova et al. 2018; Jini and Joseph, 2017; Xu et al. 2017; Xu et al. 2017; Abdul et al. 2016; Qiao et al. 2015; Nakayama et al. 2013). Our results indicated SA application up-regulated two important regulatory factors (OsNPR1, OsWRKY45) and downregulated the expression of other two transcription factors (OsWRKY7 and OsWRKY70) in SA signaling pathway. It was consistent with Chao et al. (2010) which showed that SA application enhanced OsWRKY45expression, which resulted in an increased endogenous SA content. Results of OsNPR1expression determination confirmed that OsNPR7was a positive regulator of SA signaling pathway (Lai et al. 2018; Xu et al. 2017; Nakayama et al., 2013).OsWRKY7and OSWRKY70 were also found negatively correlated with the SA contents in rice. These results supported the hypothesis that SA application could activate the SA-signaling pathway to induce the Cd response in rice.

\section{Conclusion}

In conclusion, it is evident from the present work that SA can effectively boost the antioxidant enzymes activities and SA signaling pathway to response to $\mathrm{Cd}$ stress in rice. SA spraying modulates the Cd mobility of stem-to-leaf and leafto-panicle in rice at flowering stage to reduce the $\mathrm{Cd}$ accumulation in rice grain which is helpful in developing the low-Cd rice grain (Figure 8).

\section{Declarations}

Ethics approval and consent to participate: No applicable.

Consent for publication: No applicable.

Availability of data and material: All essential data are part of the article.

Conflict of interest: The authors declare that they have no competing interests.

Funding: the Natural Science Foundation of Zhejiang Province, China (Y17C020020), the National Key Research and Development Project of China (2018YFE0111900 and 2017YFD0801104-5), the National Nature Science Foundation of China (31771698).

Authors' Contributions: This study was designed by Cheng Zhu, Zhixiang Chen and Feijuan Wang. Pot experiment was conducted by Haifeng Tan and Yiting Zhang. The data analysis was performed by Haifeng Tan, Yanfei Ding and Lihong Huang. Feijuan Wang wrote this manuscript; Cheng Zhu and Zhixiang Chen polished the manuscript.

Acknowledgements: No applicable.

\section{Abbreviations}


Cadmium, Cd; Salicylic acid, SA; reactive oxygen species, ROS; superoxide dismutase, SOD; catalases, CAT; ascorbate peroxidases, APX; NON-EXPR- ESSOR OF PR GENES 1, NPR1; L-2-aminooxygen-3-phenyl acrylic acid, AOPP; disodium ethylenediamine tetra-acetic acid, $\mathrm{Na}_{2}$-EDTA.

\section{References}

1. Abdul BW, Hemlata C, Abdul HW, Simranjeet S, Niraj U (2016) Salicylic acid to decrease plant stress. Environ Chem Lett 15. doi:10.1007/s10311-016-0584-0

2. Agami RA and Mohamed GF (2013) Exogenous treatment with indole-3-acetic acid and salicylic acid alleviates cadmium toxicity in wheat seedlings. Ecotoxicol Environ Saf 94: 164-171

3. Ahmad F, Mohammad F, Fareen S, Husna S, Shamsul H (2019) Supplementation of Salicylic Acid and Citric Acid for Alleviation of Cadmium Toxicity to Brassica juncea. J Plant Growth Regul 1-15. doi:10.1007/s00344-019$10007-0$

4. Amit PS, GarimaD, Seema M, Sanjay D, Manish T, Shekhar M, Vivek P, Praboodh KT, Debasis C, Rudra DT (2015) Salicylic acid modulates arsenic toxicity by reducing its root to shoot translocation in rice(Oryza sativa L.). Front Plant Sci 6: 340. doi:10.3389/fpls.2015.00340

5. Bai X, Dong Y, Kong J, Xu L, Liu S (2014) Effects of application of salicylic acid alleviates cadmium toxicity in perennial ryegrass. Plant Growth Regul 75:695-706

6. Biswas T, Mathur A, Gupta V, Singh M, Mathur AK (2019) Salicylic acid and ultrasonic stress modulated gene expression and ginsenoside production in differentially affected Panax quinquefolius (L.) and Panax sikkimensis (Ban.) cell suspensions. Plant Cell Tiss Org 136: 575-588.

7. Blanco F, Salinas P, Cecchini NM, JordanaX, Van Hummelen P, Alvarez ME, Holuigue L (2009) Early genomic responses to salicylic acid in Arabidopsis. Plant Mol Biol 70: 79-102.

8. Chao YY, Chen CY, Huang WD, Kao CH (2010) Salicylic acid mediated hydrogen peroxide accumulation and protection against $\mathrm{Cd}$ toxicity in rice leaves. Plant Soil 329:327-337

9. Emad H and Mohamed F (2019) Efficacy of salicylic acid as a cofactor for ameliorating effects of water stress and enhancing wheat yield and water use efficiency in saline soil. Int J Plant Prod 13:163-176.

10. Guo B, Liang Y, Zhu Y (2009) Does salicylic acid regulate antioxidant defense system, cell death, cadmium uptake and partitioning to acquire cadmium tolerance in rice? J Plant Physiol 166: 20-31

11. Guo B, Liang Y, Zhu Y, Zhao F (2007) Role of salicylic acid in alleviating oxidative damage in rice roots (Oryza sativa) subjected to cadmium stress. Environ Pollut 147:743-749

12. Guo JK, Zhou R, Ren XH, Jia HL, Hua L, Xu HH, Lv X, Zhao J, Wei T (2018) Effects of salicylic acid, Epi-brassinolide and calcium on stress alleviation and Cd accumulation in tomato plants. Ecoto Environ Safet 157: 491-496. doi:10.1016/j.ecoenv.2018.04.010.

13. Guo PR, Li ZH, Huang PX, Li BS, Fang S, Chu JF, Guo HW (2017) A tripartite amplification loop involving the transcription factor WRKY75, salicylic acid, and reactive oxygen species accelerates leaf senescence. The Plant Cell 29: 2854-2870.

14. Hasanuzzaman M and Fujita M (2012) Heavy metals in the environment: current status, toxic effects on plants and possible phytoremediation. In: Anjum NA, Pereira MA, Ahmad I, Duarte AC, Umar S, Khan NA (eds) Phytotechnologies: remediation of environmental contaminants. Boca Raton, CRC Press, pp. 7-73

15. Huang ZA, Jiang DA, Yang Y, Sun JW, Jin SH (2004) Effects of nitrogen deficiency on gas exchange, chlorophyll fluorescence, and antioxidant enzymes in leaves of rice plants. Photosynthetica 42: 357-364. 
16. Jana S and Choudhuri MA (1981) Glycolate metabolism of three submerged aquatic angiosperm during aging. Aquat Bot 12: 345-354.

17. Jini D and Joseph B (2017) Physiological mechanism of salicylic acid for alleviation of salt stress in rice. Rice Sci 24: $97-108$.

18. Knudson LL, Tibbitts TW, Edwards GE (1977) Measurement of ozone injury by determination of leaf chlorophyll concentration. Plant Physiol 60: 606-608.

19. Lai YS, Renna L, Yarema J, Ruberti C, He SY, Brandizzi F (2018) Salicylic acid-independent role of NPR1 is required for protection from proteotoxic stress in the plant endoplasmic reticulum. P Natl Acad Sci USA 115: E5203-E5212.

20. Liu ZP, Ding YF, Wang FJ, Ye YY, Zhu C (2016a) Role of salicylic acid in resistance to cadmium stress in plants. Plant Cell Rep 35:719-731.

21. Liu ZP, Zhang QF, Han TQ, Ding YF, Sun JW, Wang FJ, Zhu C (2016b) Heavy metal pollution in a soil-rice system in the Yangtze River region of China. Int J Environ Res Public Health 13, 63

22. Metwally A, Finkemeier I, Georgi M, Dietz KJ (2003) Salicylic acid alleviates the cadmium toxicity in barley seedlings. Plant Physiol 132:272-281

23. Muhammad R, Shafaqat A, Muhammad ZR, Sumaira M, Muhammad A, Muhammad FQ, Saud AA, Mohammed NA, Parvaiz A (2019) Effect of foliar applications of silicon and titanium dioxide nanoparticles on growth, oxidative stress, and cadmium accumulation by rice (Oryza sativa). Acta Physiol Plantarum 41:35. doi:10.1007/s11738-0192828-7

24. Nakayama A, Fukushima S, Goto S, Matsushita A, Shimono M, Sugano S,Jiang CJ, Akagi A, Yamazaki M, Inoue H, Takatsuji H (2013) Genome-wide identification of WRKY45-regulated genes that mediatebenzothiadiazole-induced defense responses in rice. BMC Plant Biol 13:150.

25. Natashia D, Sruajit B, Mrinal KM (2016) Enhanced cadmium accumulation and tolerance in transgenic tobacco overexpressing rice metal tolerance protein gene OSMTP1 is promising for phytoremediation. Plant Physiol Biochem 105:297-309.

26. Noriega G, Caggiano E, Lecube ML, Santa Cruz D, Batlle A, Tomaro M, Balestrasse KB (2012) The role of salicylic acid in theprevention of oxidative stress elicited by cadmium in soybean plants. Biometals 25:1155-1165

27. Orsolya KG, Magda P, Éva D, Tibor J, Gabriella S (2016) Salicylic acid and sodium salicylate alleviate cadmium toxicity to different extents in maize (Zea mays L.). PLoS ONE 11: e0160157. doi:10.1371/journal.pone.0160157

28. Pape S, Thurow C, Gatz C (2010) The Arabidopsis PR-1 promoter contains multiple integration sites for the coactivator NPR1 and the repressor SNI1. Plant Physiol 154: 1805-1818.

29. Qiao ZJ, Jing T, Liu ZQ, Zhang LP, Jin ZP, Liu DM, Pei YX (2015) $\mathrm{H}_{2}$ S acting as a downstream signaling moleculeof SA regulates Cd tolerance in Arabidopsis. Plant Soil 393: 137-146.

30. Sajitha RS and Murugan K (2010) Purification and kinetic characterization of the liverwort Pallavicinia lyelli (Hook.) S.Gray. cytosolic ascorbate peroxidase. Plant PhysiolBiochem 48:758-763.

31. Shimo H, Ishimaru Y, An G, Yamakawa T, Nakanishi H, Nishizawa N (2011) Low cadmium (LCD), a novel gene related to cadmiumtolerance and accumulation in rice. J Exp Bot 62:5727-5734.

32. Uraguchi S, Kamiya T, Clemens S, Fujiwara T (2014) Characterization of OsLCT1, a cadmium transporter from indica rice (Oryza sativa). Physiol Plantarum 151:339-347.

33. Vlot AC, Dempsey DMA, Klessig DF (2009) Salicylic acid, a multifaceted hormone to combatdisease. Ann Rev Phytopathol 47: 177-206.

34. Wang FJ, Shang YS, Yang L, Zhu C (2012) Comparative proteomic study and functional analysis of translationally controlled tumor protein in rice roots under $\mathrm{Hg}^{2+}$ stress. J Environ Sci-CHINA 24: 2149-2158. 
35. Wang FJ, Zeng B, Sun, ZX, Zhu C (2009) Relationship between proline and $\mathrm{Hg}^{2+}$-induced oxidative stress in a tolerant rice mutant. Arch Environ ContamToxicol 56, 723-731.

36. Wang Q, Liang X, Dong Y, Xu L, Zhang X, Kong J, Liu S (2013a) Effects of exogenous salicylic acid and nitric oxide on physiological characteristics of perennial ryegrass under cadmium stress. J Plant Growth Regul 32:721-731

37. Wang X, Zhang ZW, Tu SH, Feng WQ, Xu F, Zhu F, Zhang DW, Du JB, Yuan S, Lin HH (2013b) Comparative study of four rice cultivars with different levels of cadmium tolerance. Biologia 68:74-81

38. Wani AB, Chadar H, Wani AH, Singh S, Niraj U (2017) Salicylic acid to decrease plant stress. Envrion Chem Lett 15 : 101-123.

39. Wei T, Lv X, Jia HL, Hua L, Xu HH, Zhou R, Zhao J, Ren XH, Guo JK (2018) Effects of salicylic acid, Fe(II) and plant growth-promoting bacteria on $\mathrm{Cd}$ accumulation and toxicity alleviation of $\mathrm{Cd}$ tolerant and sensitive tomato genotypes. J Environ Manage 214: 164-171. doi:10.1016/j.jenvman.2018.02.100

40. Wi SJ, Jang SJ, Park KY (2010) Inhibition of biphasic ethylene production enhances tolerance to abiotic stress by reducing the accumulation of reactive oxygen species in Nicotiana tabacum. Mol Cell 30: 37-49.

41. Xia XJ, Zhou YH, Shi K, Zhou J, Foyer CH, Yu JQ (2015) Interplay between reactive oxygen species and hormones in the control of plant development and stress tolerance. J Exp Bot 66: 2839-2856.

42. Xu L, Zhao HY, Ruan WY, Deng MJ, Wang F, Peng JR, Luo J, Chen ZX, Yi KK (2017) Abnormal inflorescence meristem 1 functions in salicylic acid biosynthesis to maintain proper reactive oxygen species levels for root meristem activity in rice. Plant Cell 29: 560-574.

43. Yotsova EK, Dobrikova AG, Stefanov MA, Kouzmanova M, Apostolova EL (2018) Improvement of the rice photosynthetic apparatus defence under cadmium stress modulated bysalicylic acid supply to roots. Theor Exp Plant Phys 30: 57-70.

44. Yuan LY, Yang SG, BX, Zhang M, Wu KQ (2012) Molecular characterization of a rice metal tolerance protein, OsMTP1. Plant Cell Rep 31:67-79.

45. Zawoznik MS, Groppa MD, Tomaro ML, Benavides MP (2007) Endogenous salicylic acid potentiates cadmiuminduced oxidative stress in Arabidopsis thaliana. Plant Sci 173:190-197

46. Zhao XY, Chen HQ, Jiang H, Zhong MS, You CX, Li YY, Hao YJ (2019) WRKY15 improves resistance of apple to Botryosphaeria dothidea via the salicylic acid-mediated pathway by directly binding the MdICS1 promoter. J Integr Plant Biol doi: 10.1111/jipb.12825

47. Zhou Q, Shao GS, Zhang YX, Dong Q, Wang H, Cheng SH, Cao LY, Shen XH (2017) The difference of Cadmium accumulation between the indica and japonica subspecies and the mechanism of it. Plant Growth Regul 81: 523532.

48. Zoltán T, Péter P, Péter B, Zalán C, Gabriella S, Irma T (2018) $\mathrm{H}_{2} \mathrm{O}_{2}$ homeostasis in wild-type and ethyleneinsensitive never ripe tomato in response to salicylic acid treatment in normal photoperiod and in prolonged darkness. Plant physiol biochem 126: 74-85.

\section{Tables}

Table 1 qRT-PCR primers for Gene expression analysis in leaves of rice plants 


\begin{tabular}{cc}
\hline Primer names & Sequence (5'-3') \\
\hline OsLCT1-F & GAGTTCTTCGTCAGAGCTAC \\
OsLCT1-R & CAGTGCTGGATGACGAATTG \\
OsLCD-F & ACCGACTGCACAGTAATCAAGC \\
OsLCD-R & TTACTTCTGCGAGTGTGAGCAA \\
Os $M T P 1-\mathrm{F}$ & GGTCCTGATGGAGAGCACGC \\
Os $M T P 1-\mathrm{R}$ & CTACTCGCGCTCAATCTGAA \\
OsPAL-F & GAGCTTGGACTACGGCTTCAA \\
OsPAL- $R$ & CGCTCTGGACATGGTTGGT \\
OsICS1-F & TCTGCGATGATGTGGTTGTC \\
OsICS1-R & GCTCGGATGAAGAGTATTTAGGA \\
OsNPR1-F & TGGACAGGTTATCACCATTGGT \\
OsNPR1-R & CCGCAGCTTCCATTCCTATG \\
OsWRKY45-F & AGCTGAGCTGCGAGGAAGA \\
OsWRKY45-R & CGAAAGCGGAAGAACAGGA \\
OsWRKY7-F & TGATCGAGATAGCAGCCTCTT \\
OsWRKY7-R & CCAGCTACATCCAAAATGACC \\
OsWRKY70-F & CCGCTGCTGTTTTGATCATCT \\
OsWRKY70-R & GGAGCTAAGCTAACTCACTCCACA \\
\hline
\end{tabular}

Table 2 Effects of different treatments on agronomic traits of rice under Cd stress at the reproductive stages (heading and flowering stage)

\begin{tabular}{|c|c|c|c|c|c|c|c|c|}
\hline \multirow{2}{*}{$\begin{array}{c}\text { Different } \\
\text { treatment }\end{array}$} & \multicolumn{4}{|c|}{ Heading Stage } & \multicolumn{4}{|c|}{ Flowering stage } \\
\hline & $\begin{array}{l}\text { Root length } \\
\text { (cm) }\end{array}$ & $\begin{array}{l}\text { Plant height } \\
\text { (cm) }\end{array}$ & $\begin{array}{l}\text { Root Dw } \\
\text { plant }^{-1}(\mathrm{~g})\end{array}$ & $\begin{array}{l}\text { Shoot Dw } \\
\text { plant }^{-1}(\mathrm{~g})\end{array}$ & $\begin{array}{l}\text { Root length } \\
\text { (cm) }\end{array}$ & $\begin{array}{l}\text { Plant height } \\
\text { (cm) }\end{array}$ & $\begin{array}{l}\text { Root Dw } \\
\text { plant }^{-1}(\mathrm{~g})\end{array}$ & $\begin{array}{l}\text { Shoot Dw } \\
\text { plant }^{-1}(\mathrm{~g})\end{array}$ \\
\hline CK & $12.84 \pm 0.67 \mathrm{a}$ & $86.20 \pm 4.32 \mathrm{a}$ & $0.43 \pm 0.02 a$ & $11.69 \pm 0.27 a$ & $12.94 \pm 0.85 a$ & $88.60 \pm 3.05 a$ & $0.43 \pm 0.01 \mathrm{a}$ & $12.50 \pm 0.14 a$ \\
\hline $\begin{array}{c}\text { SA } \\
\text { AOPP }\end{array}$ & $\begin{array}{l}12.88 \pm 0.46 a \\
12.88 \pm 0.72 a\end{array}$ & $\begin{array}{c}86.40 \pm 2.7 a \\
84.60 \pm 3.91 a\end{array}$ & $\begin{array}{l}0.42 \pm 0.02 a \\
0.43 \pm 0.03 a\end{array}$ & $\begin{array}{l}11.51 \pm 0.26 \mathrm{a} \\
11.54 \pm 0.26 \mathrm{a}\end{array}$ & $\begin{array}{l}12.60 \pm 0.96 \mathrm{a} \\
12.64 \pm 0.62 \mathrm{a}\end{array}$ & $\begin{array}{l}90.00 \pm 4.74 a \\
85.60 \pm 4.04 a\end{array}$ & $\begin{array}{l}0.43 \pm 0.05 a \\
0.43 \pm 0.03 a\end{array}$ & $\begin{array}{l}12.52 \pm 0.14 a \\
12.36 \pm 0.26 a\end{array}$ \\
\hline $\begin{array}{c}\mathrm{Cd} \\
\mathrm{SA}+\mathrm{Cd}\end{array}$ & $\begin{array}{l}9.22 \pm 0.65 b \\
8.92 \pm 0.61 b\end{array}$ & $\begin{array}{l}76.40 \pm 3.21 b \\
84.80 \pm 2.39 a\end{array}$ & $\begin{array}{l}0.42 \pm 0.02 \mathrm{a} \\
0.42 \pm 0.05 \mathrm{a}\end{array}$ & $\begin{array}{c}9.36 \pm 0.21 b \\
11.46 \pm 0.31 \mathrm{a}\end{array}$ & $\begin{array}{l}8.94 \pm 0.41 b \\
8.64 \pm 0.50 b\end{array}$ & $\begin{array}{l}76.60 \pm 1.82 \mathrm{~b} \\
88.80 \pm 4.32 \mathrm{a}\end{array}$ & $\begin{array}{l}0.42 \pm 0.01 a \\
0.43 \pm 0.03 a\end{array}$ & $\begin{array}{l}11.04 \pm 0.18 b \\
12.54 \pm 0.13 a\end{array}$ \\
\hline $\mathrm{AOPP}+\mathrm{Cd}$ & $9.06 \pm 0.55 b$ & $72.80 \pm 2.59 b$ & $0.43 \pm 0.05 a$ & $9.27 \pm 0.17 \mathrm{~b}$ & $8.70 \pm 0.72 b$ & $76.60 \pm 3.51 b$ & $0.42 \pm 0.02 \mathrm{a}$ & $11.01 \pm 0.13 \mathrm{~b}$ \\
\hline
\end{tabular}

Note: Values are mean $\pm \mathrm{SD}(\mathrm{n}=5)$; different small letters in the same column indicate significant difference at $P<0.05$.

Table 3 Effects of different treatments on agronomic traits of rice under Cd stress at mature stage

\begin{tabular}{|c|c|c|c|c|c|c|}
\hline \multirow{2}{*}{$\begin{array}{l}\text { Different } \\
\text { treatments }\end{array}$} & \multicolumn{6}{|c|}{ Mature Stage } \\
\hline & $\begin{array}{l}\text { Root length } \\
\text { (cm) }\end{array}$ & $\begin{array}{l}\text { Plant height } \\
\text { (cm) }\end{array}$ & $\begin{array}{l}\text { Root Dw plant } \\
1 \text { (g) }\end{array}$ & $\begin{array}{c}\text { Shoot Dw plant } \\
\mathbf{1} \text { (g) }\end{array}$ & $\begin{array}{c}\text { Panicle number per } \\
\text { plant }\end{array}$ & $\begin{array}{c}\text { 1000-grain weight } \\
\text { (g) }\end{array}$ \\
\hline CK & $12.88 \pm 0.54 a$ & $88.80 \pm 3.11 \mathrm{a}$ & $0.43 \pm 0.02 \mathrm{a}$ & $12.27 \pm 0.26 \mathrm{a}$ & $5.20 \pm 0.45 a$ & $27.77 \pm 0.56 \mathrm{a}$ \\
\hline SA & $12.84 \pm 0.43 a$ & $90.40 \pm 3.21 \mathrm{a}$ & $0.43 \pm 0.04 a$ & $12.17 \pm 0.20 \mathrm{a}$ & $5.00 \pm 0.00 \mathrm{a}$ & $28.18 \pm 0.60 \mathrm{a}$ \\
\hline AOPP & $12.84 \pm 0.38 \mathrm{a}$ & $87.80 \pm 4.32 \mathrm{a}$ & $0.45 \pm 0.04 a$ & $12.31 \pm 0.22 \mathrm{a}$ & $5.60 \pm 0.89 a$ & $28.40 \pm 0.79 a$ \\
\hline $\mathrm{Cd}$ & $8.94 \pm 0.54 b$ & $79.20 \pm 4.49 b$ & $0.43 \pm 0.03 a$ & $10.04 \pm 0.31 \mathrm{~b}$ & $5.20 \pm 0.45 a$ & $25.86 \pm 0.58 b$ \\
\hline $\mathrm{SA}+\mathrm{Cd}$ & $8.84 \pm 0.48 b$ & $89.60 \pm 2.30 \mathrm{a}$ & $0.42 \pm 0.03 a$ & $12.26 \pm 0.07 a$ & $5.20 \pm 0.45 a$ & $25.70 \pm 0.45 b$ \\
\hline $\mathrm{AOPP}+\mathrm{Cd}$ & $8.72 \pm 0.61 b$ & $75.00 \pm 3.08 b$ & $0.43 \pm 0.04 a$ & $10.02 \pm 0.39 b$ & $5.40 \pm 0.89 a$ & $25.33 \pm 0.82 \mathrm{~b}$ \\
\hline
\end{tabular}

Note: Values are mean $\pm \mathrm{SD}(\mathrm{n}=5)$; different small letters in the same column indicate significant difference at $P<0.05$.

Table 4 Effects of different treatments on Cd mobility in rice 


\begin{tabular}{ccccc}
\hline Growth stages treatments & \multicolumn{3}{c}{ Mobility (\%) } \\
\cline { 2 - 5 } & \multicolumn{5}{c}{ Roots-to-Stems Stems-to-Leaves Leaves-to- panicles } \\
& \multicolumn{4}{c}{} \\
\hline Heading stage & $\mathrm{Cd}$ & $91.27 \pm 1.98 \mathrm{a}$ & $6.52 \pm 0.57 \mathrm{a}$ & $12.73 \pm 0.74 \mathrm{a}$ \\
& $\mathrm{SA}+\mathrm{Cd}$ & $91.62 \pm 0.39 \mathrm{a}$ & $6.49 \pm 0.15 \mathrm{a}$ & $12.40 \pm 0.96 \mathrm{a}$ \\
\cline { 2 - 5 } Flowering stage & $\mathrm{AOPP}+\mathrm{Cd}$ & $91.43 \pm 3.36 \mathrm{a}$ & $6.31 \pm 0.61 \mathrm{a}$ & $12.48 \pm 0.73 \mathrm{a}$ \\
\cline { 2 - 5 } & $\mathrm{Cd}$ & $127.15 \pm 7.31 \mathrm{a}$ & $17.16 \pm 1.24 \mathrm{~b}$ & $30.34 \pm 0.96 \mathrm{~b}$ \\
\cline { 2 - 5 } Mature stage & $\mathrm{SA}+\mathrm{Cd}$ & $127.43 \pm 0.34 \mathrm{a}$ & $12.63 \pm 1.31 \mathrm{c}$ & $17.98 \pm 0.65 \mathrm{c}$ \\
\cline { 2 - 5 } & $\mathrm{AOP}+\mathrm{Cd}$ & $127.63 \pm 1.30 \mathrm{a}$ & $26.02 \pm 3.08 \mathrm{a}$ & $44.73 \pm 3.28 \mathrm{a}$ \\
\cline { 2 - 5 } & $\mathrm{SA}+\mathrm{Cd}$ & $195.71 \pm 19.25 \mathrm{a}$ & $2.11 \pm 0.14 \mathrm{a}$ & $212.03 \pm 25.85 \mathrm{~b}$ \\
\cline { 2 - 5 } & $\mathrm{AOPP}+\mathrm{Cd}$ & $195.17 \pm 11.04 \mathrm{a}$ & $2.14 \pm 0.17 \mathrm{a}$ & $274.34 \pm 8.84 \mathrm{a}$ \\
\hline
\end{tabular}

Note: Values are mean \pm SD $(n=5)$; different small letters in the same column indicate significant difference at $P<0.05$.

\section{Figures}

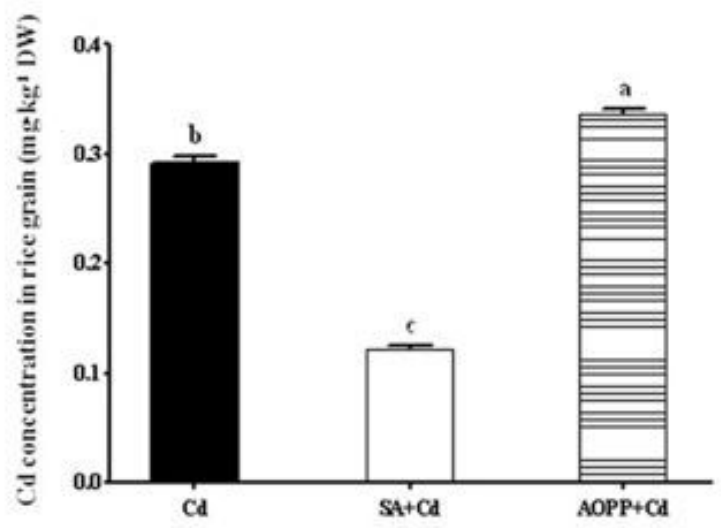

Figure 1

Effects of different treatments on Cd accumulation in brown rice at mature stage 

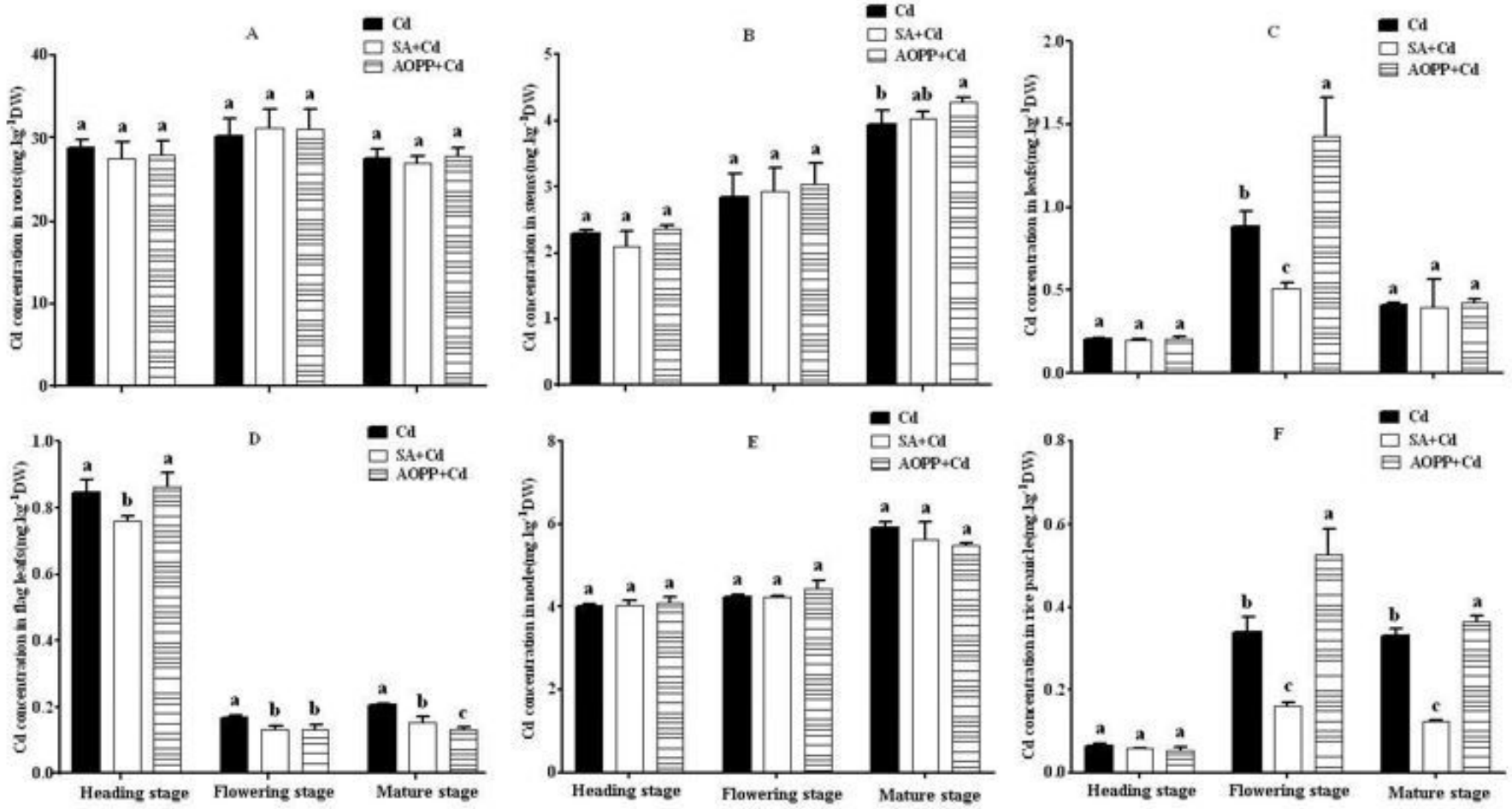

Figure 2

Effects of different treatments on the accumulation of $\mathrm{Cd}$ in different parts of rice at the reproductive growth stage. A, roots; $B$, stems; C, leaves; $D$, flag leaves; E, nodes; F, panicles

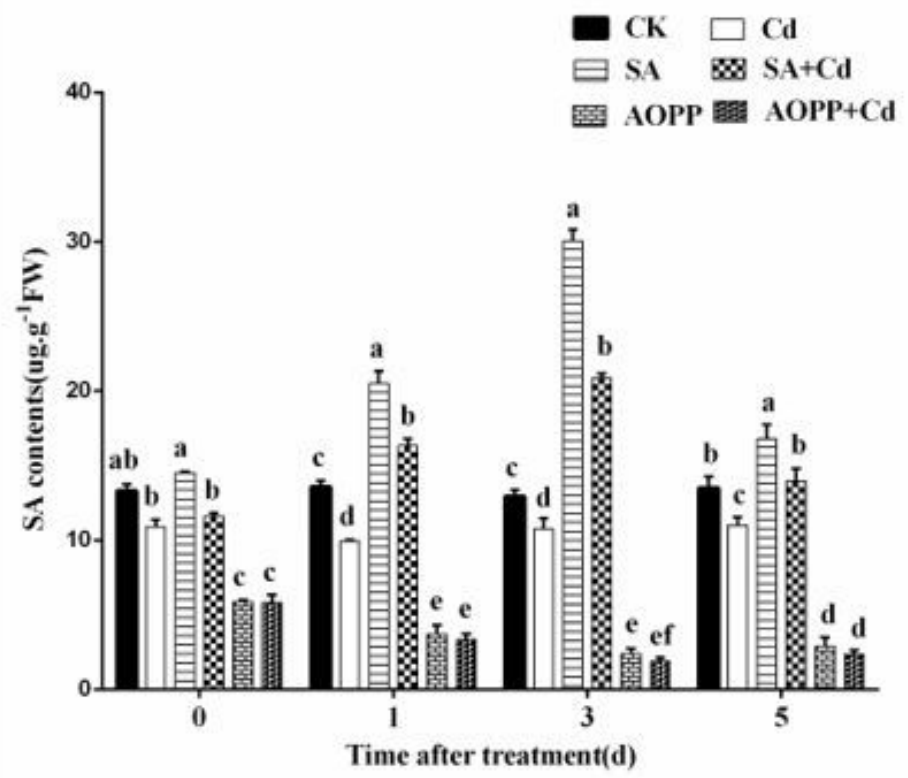

Figure 3

Effects of SA treatment on SA content of leaves at flowering stage 

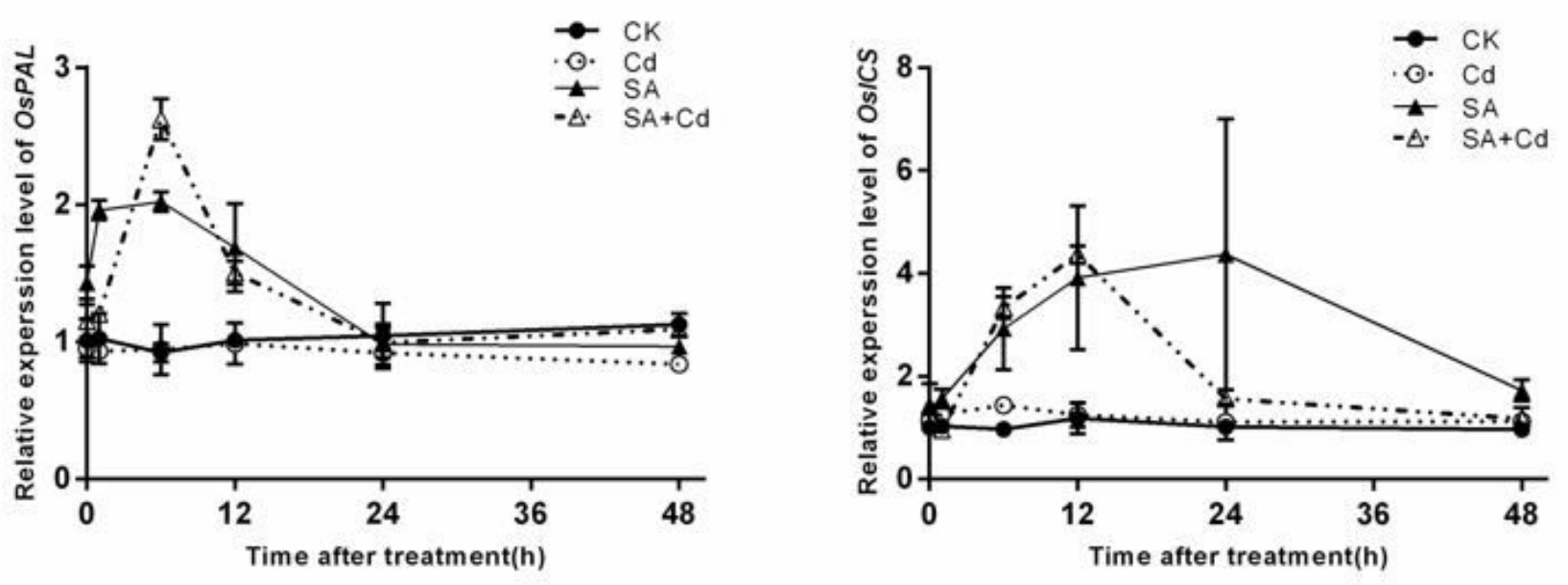

Figure 4

Effects of SA treatment on the expression levels of OsPAL and OsICS in rice leaves at flowering stage
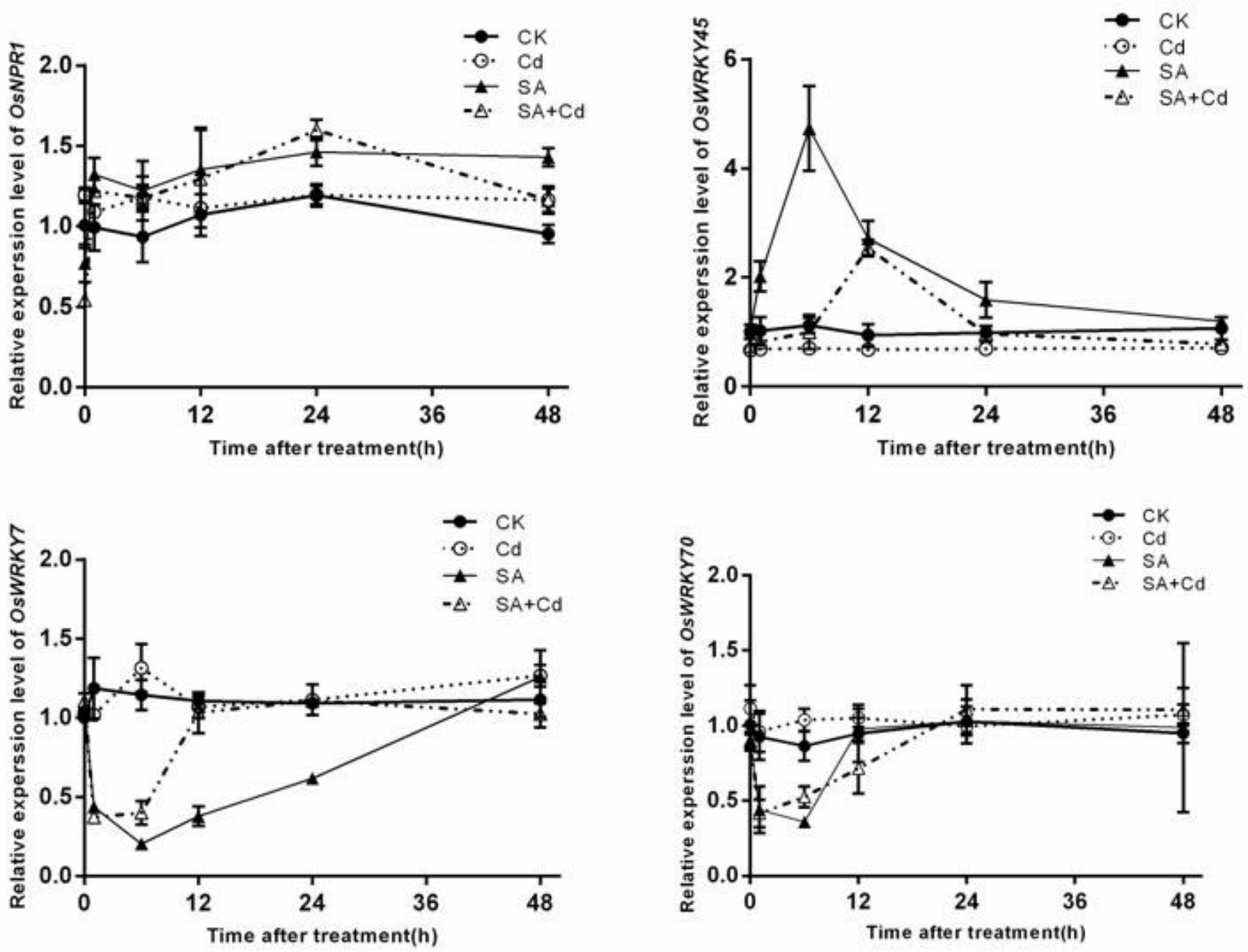

Figure 5

Effects of SA treatment on the expression levels of OsNPR1, OsWRKY45, OsWRKY7, and OsWRKY70 in rice leaves at flowering stage 

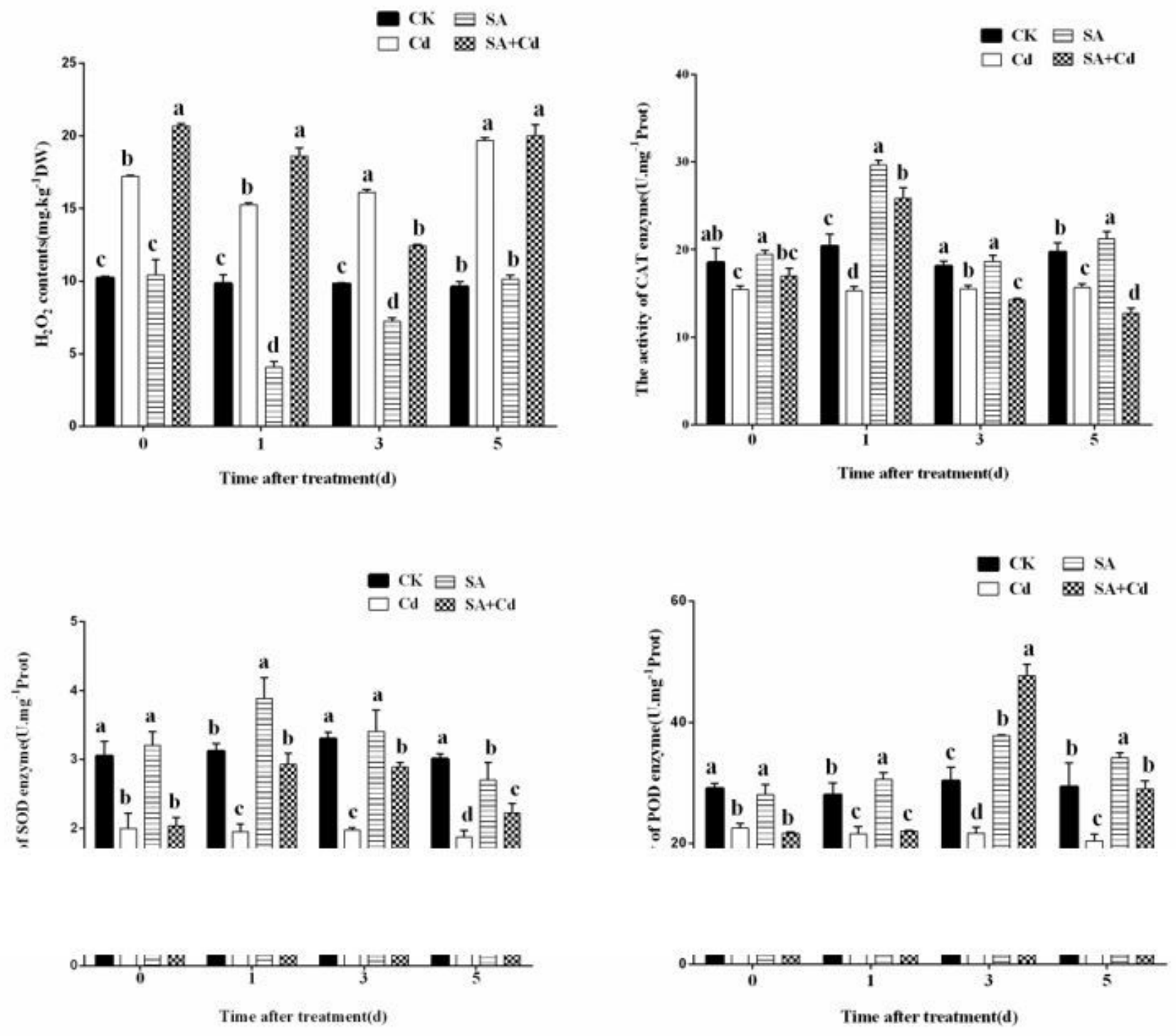

Figure 6

Effects of SA treatment on the H2O2 contents and antioxidant enzymes' activities (CAT, POD, and APX) in rice leaves at flowering stage
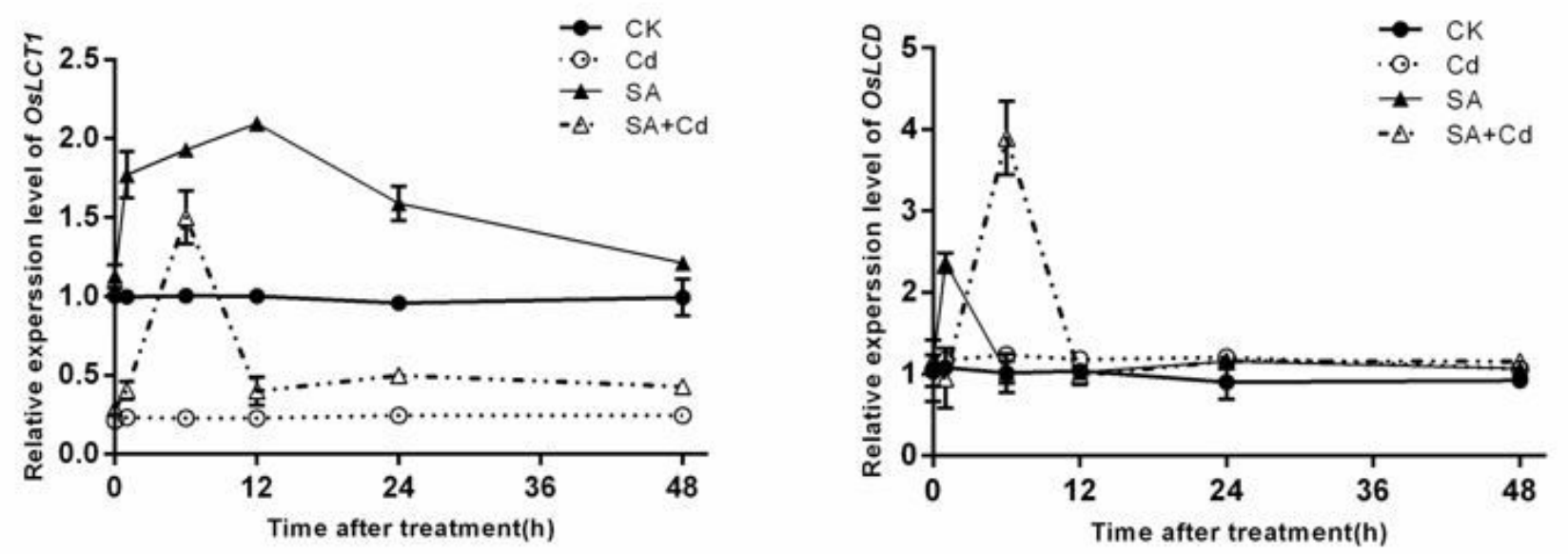
Figure 7

Effects of SA treatment on the expression levels of OsLCT1 and OsLCD in rice leaves at flowering stage 